\title{
Article
}

\section{Alien Invasive Plant Effect on Soil Fauna Is Habitat Dependent}

\author{
Tania De Almeida ${ }^{1}$ (D), Estelle Forey ${ }^{2}$ D and Matthieu Chauvat ${ }^{2, *}$ (D) \\ 1 AgroParisTech, INRAE, Université Paris-Saclay, UMR ECOSYS, 78850 Thiverval-Grignon, France; \\ tania.almeida@outlook.fr \\ 2 ECODIV, INRAE, Normandie Université, UNIROUEN, 76000 Rouen, France; Estelle.forey@univ-rouen.fr \\ * Correspondence: matthieu.chauvat@univ-rouen.fr
}

check for

updates

Citation: De Almeida, T.; Forey, E.; Chauvat, M. Alien Invasive Plant Effect on Soil Fauna Is Habitat Dependent. Diversity 2022, 14, 61. https://doi.org/10.3390/d14020061

Academic Editor: Michael Wink

Received: 14 December 2021

Accepted: 16 January 2022

Published: 18 January 2022

Publisher's Note: MDPI stays neutral with regard to jurisdictional claims in published maps and institutional affiliations.

Copyright: (C) 2022 by the authors. Licensee MDPI, Basel, Switzerland. This article is an open access article distributed under the terms and conditions of the Creative Commons Attribution (CC BY) license (https:// creativecommons.org/licenses/by/ $4.0 /)$.

\begin{abstract}
Invasive alien plants often modify the structure of native plant communities, but their potential impact on soil communities is far less studied. In this study, we looked at the impact of invasive Asian knotweed (Reynoutria spp.) on two major soil mesofauna (Collembola) and microfauna (Nematodes) communities. We expected ingress of knotweed to differentially affect faunal groups depending on their trophic position, with the lower trophic levels being more impacted than the higher trophic groups according to the closer relationship to plants for basal trophic groups. Furthermore, we expected the knotweed impact to depend on habitat type (forest vs. meadow) with more pronounced changes in abundances of soil invertebrate in invaded meadows. Plant and soil invertebrates were sampled in six sites (three forest and three meadows) in northern France in both control and invaded plots. Our results showed that the presence of knotweed strongly reduced native plant species' diversity and abundance. Soil fauna also responded to the invasion by Asian knotweed with different responses, as hypothesized, according to trophic position or life-forms. Furthermore, abundances of several collembolan life-forms were influenced by the interaction between the factors "Habitat" and "Knotweed". This may explain the difficulty to easily generalize and predict the consequences of plant invasion on belowground diversity, although this is of crucial importance for alleviating negative consequences and costs of biological invasion.
\end{abstract}

Keywords: Reynoutria ssp.; Collembola; Nematodes; habitat type; novel ecosystems

\section{Introduction}

Biological invasions are a main concern globally as they have drastic economic and ecological impacts through replacement of native species, change in habitat structure or alteration of ecosystem functioning [1,2]. Recently, Diagne et al. [3] estimated the costs of biological invasions to consistently increase over time with an average threefold increase per decade, reaching a reported worldwide annual cost of around USD 162.7 billion in 2017. Furthermore, biological invasions are expected to increase in the future, being exacerbated by globalization and interactions with a number of other components including urbanization, over-exploitation, climate change and agricultural intensification.

Despite progress in generalizing the impacts of invasive alien species, species that have successfully been introduced, established and spread beyond their native range, there remain considerable uncertainties regarding the underlying mechanisms of such impacts [4]. Native plant communities suffer from establishment and development of invasive alien plant species. Success of invasive species may result from both direct effects (e.g., allelopathy or competition with natives; [5]) or indirectly through changes in the environment [2].

Development and dynamics of terrestrial ecosystems are partly regulated by interactions taking place between above and belowground compartments. Briefly, while plants provide organic matter to the belowground system, soil organisms, e.g., soil fauna and soil microorganisms, through decomposition and mineralization processes, regulate the delivery rate of nutrients back to the plants. Recently, Forey et al. [6] showed that an invasive 
palm tree, Pinanga coronata, on a South Pacific Island, led to weakening of the plant-soil fauna relationships (i.e., trait-matching) compared to the more stable relationships in noninvaded plots. In different recent meta-analyses, it was shown that habitat-context, mainly open (e.g., meadows) versus closed habitats (e.g., forests), strongly interact with the trophic position of an organism to determine the response of soil fauna to the presence of invasive species, and that stronger responses were observed in open habitats $[7,8]$. This supports the hypothesis that invasive alien plant (IAP) species can alter the quantity, quality and timing of litter production. This would alter nutrient inputs into the soil, altering linkages with biota belowground and their associated functions such as mineralization, and inducing feedbacks to the plant assemblages' structure and dynamic [9]. These plant-soil feedbacks may in turn contribute to promote seedling establishment of invasive species (results from a meta-analysis performed on 68 species, [10]).

Several IAP species are described to release allelopathic compounds into their environment. This refers to the novel weapon hypothesis $(\mathrm{NWH})$ suggesting that alien plant species may become invasive according to their possession of deleterious secondary compounds unknown to the native species in the invasion range. This is the case of a well-known invasive plant complex in Europe, the Asian knotweed species complex. Composed of two distinct species Reynoutria japonica (Houttuyn), R. sachalinensis (F. Schmidt) and a hybrid R. $\times$ bohemica (Chrtek \& Chrtková), these species originating from eastern Asia have now colonized numerous countries on both hemispheres [11]. Their impacts have been recently reviewed [12] and, although studies agree on their negative effects on the diversity of native flora and aboveground fauna, mostly due to a considerable amount of litter-leaf and stems produced, their impacts on soil biota are, so far, little investigated and difficult to generalize, especially regarding soil meso- or microfauna. Additionally, this large amount of knotweed litter input may be more contrasting in meadows than in forests where trees already provide a high amount of leaf litter [13]. In a microcosm experiment, Abgrall et al. [13] showed that adding knotweed rhizome extract alters the soil food webs (with a positive or negative effect depending on the concentration and trophic levels), and Skubala and Mierny [14] reported a significant negative effect of knotweed on oribatid mites but no effect on Collembola. To our knowledge, only one publication [14] assessed the impact of spontaneous invaded sites upon soil mesofauna, and none have reported field data on Nematodes' responses to knotweed.

We wanted to partly fill this gap in the current knowledge by investigating the response of soil Collembola and Nematodes as members of the meso- and the microfauna, respectively, to the spontaneous and long-term invasion by Asian knotweed ( $>10$ years). Nematode species belong to different trophic groups, e.g., bacterivores, fungivores, herbivores, omnivores or predators. As reported by Abgrall et al. [13] in a laboratory study, we expect that knotweed will exert a strong influence on basal trophic groups such as herbivores or microbial-feeders, and that higher trophic levels, such as predatory Nematodes, will be less affected. By comparison, Collembola species can be separated into three ecomorphological life-forms: epedaphic, hemiedaphic, and euedaphic. These life-forms differ in fundamental ecological properties such as reproduction, vertical distribution, metabolic activity and dispersal $[15,16]$, in addition to trophic position and niche, with different food resources ranging from plant materials to microorganisms [17,18]. These life-forms differ thus in their sensitivity to environmental conditions and are commonly used to depict consequences of environmental changes [19-23]. We thus expect epedaphic species living in the litter to be impacted by the amount of litter produced by the knotweeds, especially in the invaded meadows.

Thus, we hypothesize that the litter produced by knotweed will generate new habitats for epedaphic Collembola species in invaded meadows sites, whereas in forest it will be less critical according to the pre-existing litter before invasion. However, we also cannot exclude that the decrease in resource diversity resulting from the invasion may negatively impact epedaphic species. In contrast, we expect euedaphic Collembola (i.e., deep-living species) 
to be less responsive to changes in organic matter delivery under knotweed invasion, either in forest or in meadow habitat types.

\section{Materials and Methods}

\subsection{Study Area}

We identified 1123 sites where knotweed was present in Normandy (France) through a literature and field survey. In Normandy all three knotweed species- $R$. japonica, $R$. $\times$ bohemica and $R$. sachalinensis - are present. These species can be morphologically very similar and only genetic analyses would allow a rigorous identification. Therefore, in the following text, the term knotweed refers to Reynoutria spp.

We selected six riparian sites (see Table S1) where introduced knotweed has been present for more than 10 years but has not been managed for at least seven years. At each site, both the monospecific stands of knotweed (invaded plots) and the uninvaded areas with only native vegetation (control plots) were larger than $60 \mathrm{~m}^{2}$. To compare two contrasting habitat types, we chose three sites in forest and three in meadows. For forest sites, we only sampled patches located in the core of riparian forests and we excluded sites with knotweed located at the border of stands. All sites were situated at an altitude of between 10 and $100 \mathrm{~m}$ asl.

On each site, sampling was carried out in spring 2017, in three $2 \mathrm{~m}^{2}$ quadrats in both knotweed cover classes: control (uninvaded area) and invaded (monospecific stands of knotweed). Thus, a total of 36 plots for soil fauna were sampled overall. Additionally, we also characterized habitat properties that could drive soil communities (soil variables and vegetation) on these 36 plots.

\subsection{Soil Variables}

In each quadrat, $500 \mathrm{~g}$ of soil was collected to the depth of $10 \mathrm{~cm}$ in spring 2017 to measure edaphic properties. To perform the following standard methods of analyses, the fresh soil was sieved ( $2 \mathrm{~mm}$ ). Microbial carbon biomass (microbial C) was determined by means of the fumigation-extraction method [24]. Microbial C was extracted from fumigated and unfumigated soil samples with $\mathrm{K}_{2} \mathrm{SO}_{4}\left(\right.$ at $0.2 \mathrm{~g} \mathrm{~L}^{-1}$ ) using a Shimadzu TOC-L analyzer (Shimadzu Corporation SL, Kyoto, Japan). Soil ergosterol content, a proxy of soil fungal biomass, was measured using the method proposed by Gong et al. [25]. Ammonium and nitrate content in the soil were quantified by calorimetry with a Gallery analyzer (Thermo Fisher Scientific, Waltham, MA, USA). Twenty grams of sieved fresh soil was dried at $105^{\circ} \mathrm{C}$ for $48 \mathrm{~h}$ to determine the soil humidity. The remaining soil samples were air-dried for 2 weeks for the other soil analyses. Soil $\mathrm{pH}$ was measured in a suspension with $1 \mathrm{~mol} \cdot \mathrm{L}^{-1}$ of potassium chloride $(1: 5, w / v)$ using a FiveEasy $\mathrm{pH}$ meter (Mettler Toledo, Columbus, $\mathrm{OH}, \mathrm{USA})$. The dried soil samples were ground with a ball mill (MM 200, Retsch), and used to determine the total carbon and nitrogen contents with an elemental analyzer (CHN Flash 2000 Thermo Scientific, Waltham, MA, USA). In each quadrat, we also measured the average litter thickness in triplicate (in $\mathrm{cm}$ ).

\subsection{Vegetation Survey}

Plant communities were sampled in the $2 \mathrm{~m}^{2}$ quadrats in June 2017. The abundance of each plant species was defined using a Braun-Blanquet scale [26]. They were then converted into plants' cover percentage using the median value of each Braun-Blanquet cover class. For forest sites, quadrats were placed avoiding trunks; therefore, only the understory communities were sampled.

\subsection{Soil Fauna Survey}

Soil fauna was sampled on the same day as the soil collection in spring 2017. Springtime corresponds to a common period of high soil biological activity in Normandy. 


\subsubsection{Soil Collembola}

Soil Collembola were collected in the middle of each quadrat using a 5-cm-diameter steel cylinder from the upper $10 \mathrm{~cm}$ of soil. A single core was performed per quadrat. Collembola were extracted for twelve days according to the Berlese-Tullgren method [27] and stored in $70 \%$ ethyl alcohol. Collembola individuals were assigned to each of the 3 life-forms, i.e., epedaphic, hemiedaphic, and euedaphic, according to their morphological attributes [28]. Epedaphic species were rather large species characterized by the presence of pigmentation and more than 4 ocelli on each side and a well-developed furca (i.e., Lepidocyrtus sp., Pogonognathellus sp., Neanura muscorum, Dicyrtoma fusca, Dicyrtomina minuta, Isotoma sp., Isotomurus sp., Deuterosminthurus sp., Orchesella sp., Tomocerus sp.); in contrast, euedaphic species were blind with no pigmentation and without a functional furca (i.e., Protaphorura sp., Mesaphorura sp., Paratullbergia callipygos, Isotomiella minor, Megalothorax minimus, Willemia sp., Stenaphorurella sp., Arrhopalites sp.). Finally, species that did not fall into the previous two categories were considered as hemiedaphic (i.e., Folsomia quadrioculata, F. manolachei, Parisotoma notabilis, Friesea sp., Ceratophysella sp., Pseudosinella sp., Sminthurinus aureus, Sphareridia pumilis).

\subsubsection{Soil Nematoda}

Soil Nematoda were sampled using the same protocol as for Collembola with a steel corer. Then, for each sample, to facilitate extraction, two subsamples of $100 \mathrm{~g}$ fresh soil were extracted for two days using the Baermann funnel method [29]. After extraction, both subsamples of a single sample were combined for further analyses. First, live specimens were counted under a stereomicroscope. Then, they were fixed in $4 \%$ formalin solution and mounted on glass slides. Under a microscope the first two hundred individuals encountered were divided into the following trophic groups [30]: bacterial feeder, fungal feeder, plant feeder and omnivorous-predatory, based on their morphological attributes.

\subsection{Data Analyses}

Prior to statistical analyses, all data distributions were examined using the ShapiroWilk test of normality. To test the effect of two factors-“Knotweed" with 2 levels: absence or presence, and "Habitat" with two levels: forest or meadow-and their interaction, on soil variables, plant community and soil fauna abundance, generalized linear mixed models (GLMMs) with nested design were computed (R package "glmmTMB" [31]). In all models, a random factor was used with the samples nested in sites that were nested in "Habitats". Total carbon, total nitrogen, $\mathrm{C}: \mathrm{N}$ ratio, nitrate, microbial biomass, ergosterol and humidity were fitted with a Gaussian distribution. Other abiotic variables and plant community parameters were fitted with a gamma distribution, whereas soil fauna abundances were fitted with a zero-inflated negative binomial model (with family "nbinom2" [32]). Models were followed by Tukey HSD post-hoc tests using the package "emmeans". Significance thresholds for post hoc analyses were set at $p$-value $<0.05$.

Changes in plant community composition were visualized via non-metric multidimensional scaling (NMDS) based on the Bray-Curtis dissimilarity index to ordinate the characteristics of plant communities (composition and abundance). Differences in plant community composition were tested by permutation multivariate analysis using the Adonis function (R package "vegan" [33]). To complement previous analyses, we conducted a principal component analysis (PCA) ordination of 10 variables (C:N ratio, nitrate, microbial biomass, ergosterol, relative soil humidity, litter thickness, plant species richness, total plant cover, total Collembola and total Nematoda abundances) based on the 36 quadrats monitored (R package "FactoMineR" [34]).

All statistical analyses were performed using R software v. 4.1.0 (R Foundation for Statistical Computing). Soil (abiotic and biotic) and vegetation data are compiled within Table S2. 


\section{Results}

\subsection{Soil Variables}

Three variables were impacted by the factor "Knotweed", litter thickness and C:N ratio, with significantly higher values in invaded plots than in control plots (Table 1; Figure 1a) and microbial $C$ biomass, with an opposite pattern being significantly lower in invaded plots than in control plots (Table 1). C:N ratio was also significantly influenced by the interaction between "Knotweed" and "Habitat", as were soil nitrate and relative soil humidity. Although the C:N ratio did not differ between invaded plots and control plots in meadows, it did in forests with higher values (+33\%) in invaded forests compared to control forests. Although soil nitrate content was not different between the two knotweed levels (absence or presence) in forest habitats, soil nitrate content in invaded plots was more than twice as high as that in control plots in meadow habitats (Table 1). Soil humidity in both control and invaded plots in forest habitats was significantly higher than in control plots in meadow habitats.

(a)
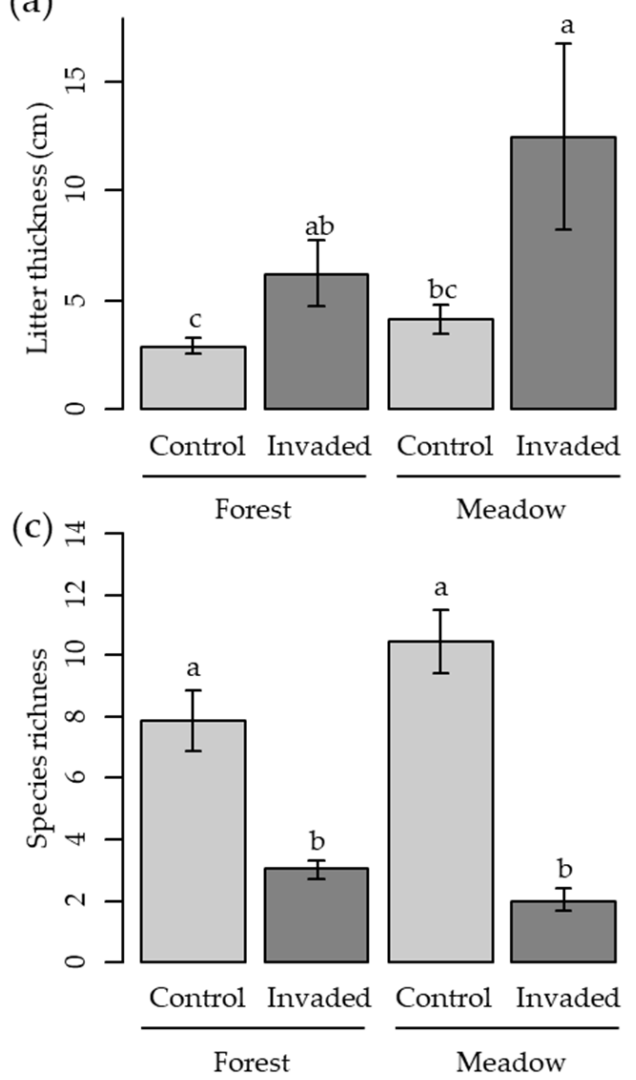

(b)

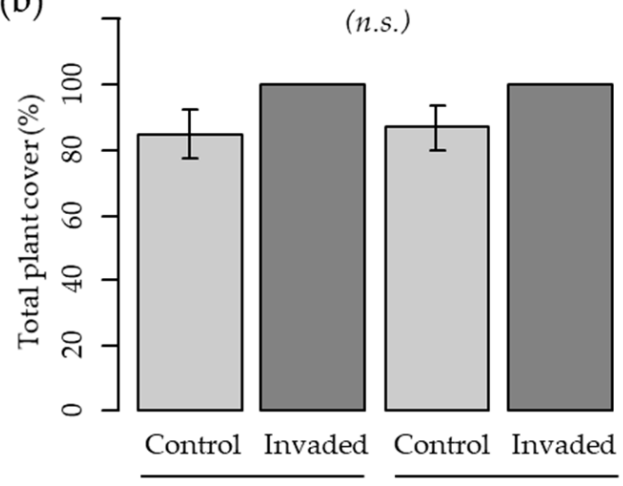

(d)

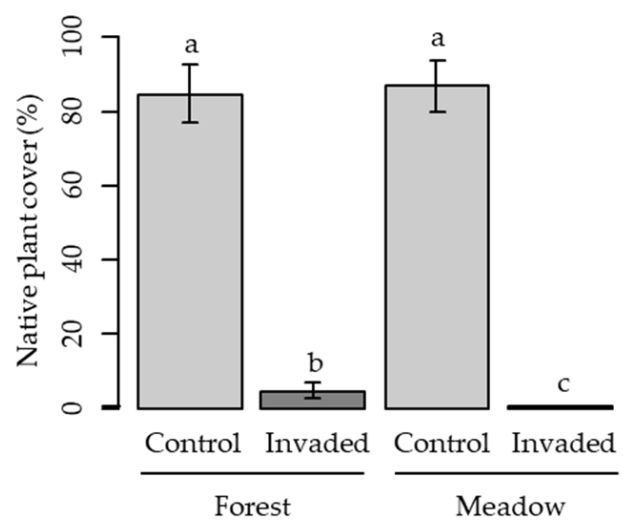

Figure 1. Effects of habitat (forest and meadow) and knotweed on (a) litter thickness and plant community parameters: (b) total plant cover; (c) plant species richness; (d) native plant cover. Values are means \pm standard errors. Significant differences according to Tukey post hoc tests are indicated by different letters. n.s.: not significant.

Finally, several variables were impacted by the factor "Habitat" with more nitrate $(+38.7 \%)$ and a higher soil humidity $(+21.2 \%)$ in forest soils compared to meadow soils, and an opposite pattern was found for ergosterol content, which was 1.8 times higher in meadows than in forests. 
Table 1. Effects of the factors "Knotweed" with two levels: presence or absence, "Habitat" with two levels: forest or meadow, and their interaction on soil variables. Values are means \pm standard errors. z-values and associated $p$-values were obtained from GLMM with gamma or Gaussian distributions. Two values in the same row with a different letter are significantly different according to Tukey post hoc tests. ${ }^{*}{ }^{* *}$, and ${ }^{* *}$ denote statistical significance at $p=0.05,0.01$, and 0.001 , respectively. When the $p$-values obtained from GLMM were not significant, the post hoc test results are not reported.

\begin{tabular}{|c|c|c|c|c|c|c|}
\hline & \multirow[b]{2}{*}{ z-Value } & \multirow[b]{2}{*}{$p$-Value } & \multicolumn{2}{|c|}{ Forest } & \multicolumn{2}{|c|}{ Meadow } \\
\hline & & & Control & Invaded & Control & Invaded \\
\hline \multicolumn{7}{|l|}{ Total carbon $\left(\mathrm{mg} \cdot \mathrm{g}^{-1}\right)$} \\
\hline Knotweed & 1.14 & 0.25 & $5.84 \pm 0.77$ & $6.9 \pm 1.47$ & $4.77 \pm 0.45$ & $5.67 \pm 0.38$ \\
\hline Habitat & -0.68 & 0.49 & & & & \\
\hline Knotweed $\times$ Habitat & -0.12 & 0.9 & & & & \\
\hline \multicolumn{7}{|c|}{ Total nitrogen $\left(\mathrm{mg} \cdot \mathrm{g}^{-1}\right)$} \\
\hline Knotweed & -1.48 & 0.14 & $0.39 \pm 0.05$ & $0.31 \pm 0.05$ & $0.28 \pm 0.04$ & $0.33 \pm 0.03$ \\
\hline Habitat & -1.56 & 0.11 & & & & \\
\hline Knotweed $\times$ Habitat & 1.69 & 0.09 & & & & \\
\hline \multicolumn{7}{|l|}{$\mathrm{C}: \mathrm{N}$ ratio } \\
\hline Knotweed & 3.23 & $0.001 * *$ & $15.15^{\mathrm{B}} \pm 0.91$ & $20.33^{\mathrm{A}} \pm 2.31$ & $17.55^{\mathrm{AB}} \pm 1.27$ & $17.73^{\mathrm{AB}} \pm 0.83$ \\
\hline Habitat & 0.97 & 0.33 & & & & \\
\hline Knotweed $\times$ Habitat & -2.2 & $0.03 *$ & & & & \\
\hline \multicolumn{7}{|l|}{ Nitrate $\left(\mathrm{mg} \cdot \mathrm{g}^{-1}\right)$} \\
\hline Knotweed & -0.56 & 0.58 & $1.61^{\mathrm{AB}} \pm 0.31$ & $1.47^{\mathrm{AB}} \pm 0.23$ & $0.67^{\mathrm{B}} \pm 0.2$ & $1.56^{\mathrm{A}} \pm 0.12$ \\
\hline Habitat & -2.44 & $0.01 *$ & & & & \\
\hline Knotweed $\times$ Habitat & 2.86 & $0.004^{* *}$ & & & & \\
\hline \multicolumn{7}{|l|}{ Ammonium $\left(\mathrm{mg} \cdot \mathrm{g}^{-1}\right)$} \\
\hline Knotweed & -1.39 & 0.16 & $0.91 \pm 0.23$ & $0.65 \pm 0.14$ & $0.73 \pm 0.08$ & $0.59 \pm 0.1$ \\
\hline Habitat & -0.12 & 0.91 & & & & \\
\hline Knotweed $\times$ Habitat & 0.15 & 0.88 & & & & \\
\hline \multicolumn{7}{|l|}{$\mathrm{pH}$} \\
\hline Knotweed & 0.55 & 0.59 & $6.97 \pm 0.23$ & $7.04 \pm 0.26$ & $7.56 \pm 0.09$ & $7.56 \pm 0.04$ \\
\hline Habitat & 1.58 & 0.12 & & & & \\
\hline Knotweed $\times$ Habitat & -0.4 & 0.69 & & & & \\
\hline \multicolumn{7}{|l|}{ 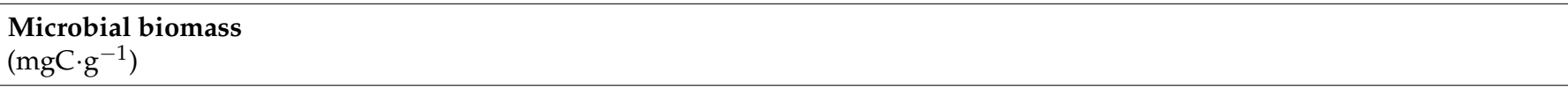 } \\
\hline Knotweed & -2.82 & $0.0049 * *$ & $0.23^{\mathrm{A}} \pm 0.04$ & $0.14^{\mathrm{B}} \pm 0.03$ & $0.2^{\mathrm{AB}} \pm 0.02$ & $0.16^{\mathrm{AB}} \pm 0.02$ \\
\hline Habitat & -0.8 & 0.43 & & & & \\
\hline Knotweed $\times$ Habitat & 1.09 & 0.28 & & & & \\
\hline \multicolumn{7}{|l|}{ Ergosterol $\left(\mu \mathrm{g} \cdot \mathrm{g}^{-1}\right)$} \\
\hline Knotweed & -1.28 & 0.2 & $1.7^{\mathrm{AB}} \pm 0.5$ & $1.1^{\mathrm{B}} \pm 0.3$ & $3.1^{\mathrm{A}} \pm 0.4$ & $2.0^{\mathrm{AB}} \pm 0.4$ \\
\hline Habitat & 1.98 & $0.048^{*}$ & & & & \\
\hline Knotweed $\times$ Habitat & -0.7 & 0.48 & & & & \\
\hline \multicolumn{7}{|l|}{ Humidity (\%) } \\
\hline Knotweed & -1.1 & 0.27 & $33.4^{\mathrm{A}} \pm 1.6$ & $31.5^{\mathrm{A}} \pm 1.4$ & $24.5^{\mathrm{B}} \pm 1.8$ & $29.0^{\mathrm{AB}} \pm 1.2$ \\
\hline Habitat & -3.71 & $<0.001^{* * *}$ & & & & \\
\hline Knotweed $\times$ Habitat & 2.54 & $0.011 *$ & & & & \\
\hline \multicolumn{7}{|l|}{ Litter thickness (cm) } \\
\hline Knotweed & 2.71 & $0.0068^{* *}$ & $2.9^{\mathrm{B}} \pm 0.4$ & $6.2^{\mathrm{AB}} \pm 1.5$ & $4.1^{\mathrm{B}} \pm 0.7$ & $12.4^{\mathrm{A}} \pm 4.3$ \\
\hline Habitat & 0.61 & 0.54 & & & & \\
\hline Knotweed $\times$ Habitat & 0.29 & 0.78 & & & & \\
\hline
\end{tabular}




\subsection{Plant Communities}

All three measured variables, plant species richness, total plant cover and native plant cover, were significantly affected by the factor "Knotweed", with species richness and native plant cover being considerably reduced in invaded plots compared to control plots, by 2.5 times and 32 times, respectively (Table 2, Figure 1). Conversely, the total plant cover increased from around $86 \%$ in control plots to $100 \%$ in invaded plots. Of the three variables, only total plant cover was not impacted by the interaction between "Knotweed" and "Habitat". Both species richness and native plant cover showed the same pattern, being significantly higher in control plots than in invaded plots, by 2.6 and 17.2 times in forests, respectively, and by 5.2, and 217 times in meadows, respectively (Table 2; Figure 1d). By contrast no significant differences were found in total plant cover between the four modalities (Table 2; Figure 1b). Finally, none of the variables responded to the factor "Habitat".

The NMDS ordination (stress $=0.11$ ) discriminated on axis 1 the control plots from the invaded ones (Figure 2). In both habitats, plant community composition and abundance differed between control and invaded quadrats (both $p$-value $<0.001$ ). The NMDS ordination discriminated on axis 2 the control plots (Figure 2). Plant community composition and abundance differed between the two habitats' control plots ( $p$-value $<0.001)$. The forest control plots were characterized by Urtica dioica L., Galium aparine L. and Rubus fruticosus L. within the understory layer. In contrast, the meadow control plots were characterized by Achillea millefolium L., Potentilla reptans L. and Agrostis capillaris L. No significant difference was found between the two habitats' invaded plots ( $p$-value $=0.99)$. Both invaded plots were mainly characterized by Reynoutria spp.

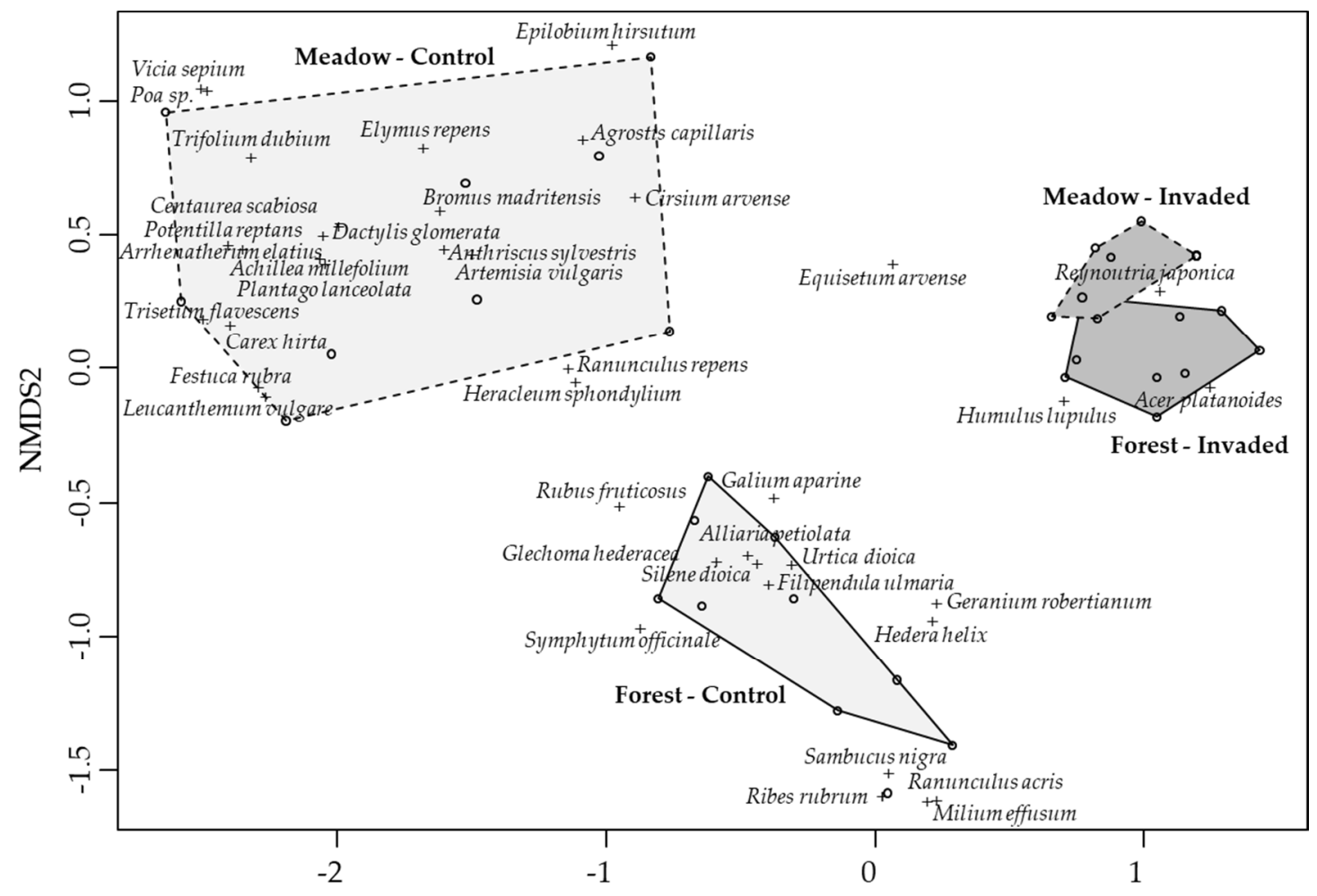

NMDS1

Figure 2. Non-metric multidimensional scaling (NMDS) (stress $=0.11$ ) performed on the plant community composition. The 9 samples of each treatment are grouped in polygons, with dashed lines for the meadow sites and full lines for the forest sites (control plots in light grey and invaded plots in dark grey). Dots represent the 36 quadrats and crosses represent the spatial location of each species. For clarity, only the plant species most correlated to the two first axes are shown. 


\subsection{Soil Fauna}

Regarding Collembola, both total and hemiedaphic abundances were impacted by the factor "Knotweed", with a decrease of $6.7 \%$ in the total collembolan abundance in invaded plots compared to control plots, but with an increase of $14.5 \%$ in hemiedaphic Collembola in invaded plots. However, with the exception of euedaphic abundance, all variables, i.e., total Collembola abundance, epedaphic abundance, and hemiedaphic abundance, were affected by the interaction term between "Knotweed" and "Habitat" (Table 2), with a different response pattern between control and invaded plots according to the habitat type. However, only the abundance of epedaphic Collembola differed significantly between the four modalities, with three times more individuals in control meadow plots than in invaded meadow plots, whereas no difference was found between control forest plots and invaded forest plots (Table 2). Finally, only the epedaphic abundance was significantly influenced by the factor "Habitat", with more individuals in meadows than in forests.

With the exception of the abundance of plant feeder Nematodes, which had about 6 times more individuals in control plots vs. invaded plots, the other trophic groups and the total Nematodes did not respond to the factors "Knotweed", "Habitat" or their interaction (Table 3). In forest habitats, abundance of plant feeders was seven times higher in control plots than in invaded plots, whereas no difference was observed between control and invaded plots in meadows (Table 3 ).

\subsection{Global Effect of Knotweed on Habitats}

The PCA did not show any clear separation between the four modalities (Figure 3). The control plots are more heterogeneous than the invaded ones in both habitat types. Invaded forest plots tend to be characterized by low Collembola and nematode abundances and plant species richness, and high litter thickness, humidity, nitrate content and total plant cover. In contrast, invaded meadows plots tend to be characterized by high Collembola and Nematoda abundances, total plant cover and litter thickness.

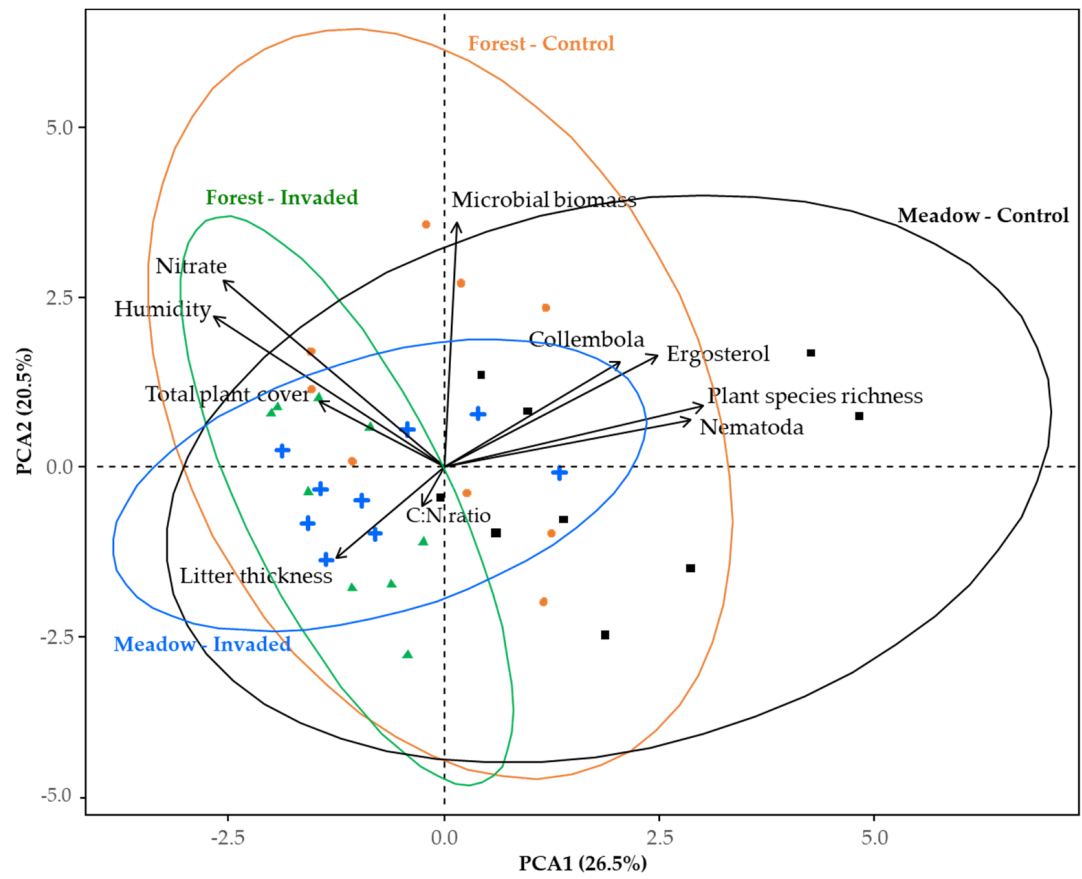

Figure 3. Principal component analysis (PCA) ordination of 10 variables (C:N ratio, nitrate, microbial biomass, ergosterol, relative soil humidity, litter thickness, plant species richness, total plant cover, total Collembola and total Nematoda abundances) based on the 36 quadrats of control forest (orange circle), invaded forest (green triangle), control meadow (black square) and invaded meadow (blue cross). Samples from each treatment $(n=9)$ are grouped within ellipses. Variables are represented by arrows. 
Table 2. Effects of the factors "Knotweed" with two levels: presence or absence, "Habitat" with two levels: forest or meadow and their interaction on plant community variables and Collembola variables (ind. $\mathrm{m}^{-2}$ ). Values are means \pm standard errors. $\mathrm{z}$-values and associated $p$-values were obtained from GLMM with a binomial negative distribution (zero-inflated models) for Collembola variables and with a gamma distribution for plant community parameters. Two values in the same row with a different letter are significantly different according to Tukey post hoc tests. ${ }^{*}, * *$, and *** denote statistical significance at $p=0.05,0.01$, and 0.001 , respectively. When the $p$-values obtained from GLMM were not significant, the post hoc test results are not reported.

\begin{tabular}{|c|c|c|c|c|c|c|}
\hline & \multirow[b]{2}{*}{ z-Value } & \multirow[b]{2}{*}{$p$-Value } & \multicolumn{2}{|c|}{ Forest } & \multicolumn{2}{|c|}{ Meadow } \\
\hline & & & Control & Invaded & Control & Invaded \\
\hline \multicolumn{7}{|l|}{$\begin{array}{l}\text { Plant community } \\
\text { variables }\end{array}$} \\
\hline \multicolumn{7}{|l|}{ Species richness } \\
\hline $\begin{array}{l}\text { Knotweed } \\
\text { Habitat } \\
\text { Knotweed } \times \text { Habitat }\end{array}$ & $\begin{array}{c}-4.28 \\
1.49 \\
-2 \\
\end{array}$ & $\begin{array}{c}<0.001^{* * *} \\
0.14 \\
0.045^{*}\end{array}$ & $7.9^{\mathrm{A}} \pm 1$ & $3.0^{\mathrm{B}} \pm 0.3$ & $10.4^{\mathrm{A}} \pm 1.1$ & $2.0^{\mathrm{B}} \pm 0.4$ \\
\hline \multicolumn{7}{|l|}{ Total plant cover (\%) } \\
\hline $\begin{array}{l}\text { Knotweed } \\
\text { Habitat } \\
\text { Knotweed } \times \text { Habitat }\end{array}$ & $\begin{array}{c}2.26 \\
0.25 \\
-0.20 \\
\end{array}$ & $\begin{array}{c}0.024^{*} \\
0.8 \\
0.84\end{array}$ & $84.7^{\mathrm{A}} \pm 7.8$ & $100^{\mathrm{A}} \pm 0$ & $86.9^{\mathrm{A}} \pm 6.8$ & $100^{\mathrm{A}} \pm 0$ \\
\hline \multicolumn{7}{|l|}{ Native plant cover $(\%)$} \\
\hline $\begin{array}{l}\text { Knotweed } \\
\text { Habitat } \\
\text { Knotweed } \times \text { Habitat }\end{array}$ & $\begin{array}{l}-4.32 \\
-0.5 \\
-3.54 \\
\end{array}$ & $\begin{array}{l}<0.001^{* * *} \\
0.61^{* * *} \\
<0.001^{* * *}\end{array}$ & $84.7^{\mathrm{A}} \pm 7.8$ & $4.9^{\mathrm{B}} \pm 1.9$ & $86.9^{\mathrm{A}} \pm 6.8$ & $0.4^{C} \pm 0.3$ \\
\hline \multicolumn{7}{|l|}{ Collembola abundance } \\
\hline $\begin{array}{l}\text { Knotweed } \\
\text { Habitat } \\
\text { Knotweed } \times \text { Habitat }\end{array}$ & $\begin{array}{c}-2.5 \\
-0.74 \\
3.21\end{array}$ & $\begin{array}{c}0.013 * \\
0.46 \\
0.0013 \text { ** }\end{array}$ & $26,056^{\mathrm{A}} \pm 5594$ & $\begin{array}{c}13,333^{\mathrm{A}} \pm \\
3593\end{array}$ & $22,611^{\mathrm{A}} \pm 8924$ & $32,055^{\mathrm{A}} \pm 9320$ \\
\hline \multicolumn{7}{|l|}{ Epedaphic abundance } \\
\hline $\begin{array}{l}\text { Knotweed } \\
\text { Habitat } \\
\text { Knotweed x Habitat }\end{array}$ & $\begin{array}{c}1.48 \\
3.4 \\
-2.8 \\
\end{array}$ & $\begin{array}{c}0.14 \\
<0.001^{* * *} \\
0.0052^{* *}\end{array}$ & $556^{\mathrm{B}} \pm 155$ & $556^{\mathrm{AB}} \pm 242$ & $1722^{\mathrm{A}} \pm 657$ & $556^{\mathrm{B}} \pm 194$ \\
\hline \multicolumn{7}{|c|}{ Hemiedaphic abundance } \\
\hline $\begin{array}{l}\text { Knotweed } \\
\text { Habitat } \\
\text { Knotweed } \times \text { Habitat }\end{array}$ & $\begin{array}{c}-2.09 \\
-0.49 \\
2.59 \\
\end{array}$ & $\begin{array}{c}0.037^{*} \\
0.62 \\
0.0097^{* *}\end{array}$ & $15,278^{\mathrm{A}} \pm 3436$ & $9611^{\mathrm{A}} \pm 2652$ & $10,000^{\mathrm{A}} \pm 3123$ & $19,333^{\mathrm{A}} \pm 5428$ \\
\hline \multicolumn{7}{|l|}{ Euedaphic abundance } \\
\hline $\begin{array}{l}\text { Knotweed } \\
\text { Habitat } \\
\text { Knotweed } \times \text { Habitat }\end{array}$ & $\begin{array}{c}-1.52 \\
-0.06 \\
1.65\end{array}$ & $\begin{array}{c}0.13 \\
0.95 \\
0.098\end{array}$ & $10,167 \pm 2981$ & $4055 \pm 823$ & $10,889 \pm 6628$ & $12,167 \pm 4349$ \\
\hline
\end{tabular}


Table 3. Effects of the factors "Knotweed" with two levels: presence or absence, "Habitat" with two levels: forest or meadow and their interaction on Nematoda abundances (ind.100 g of dry soil). Values are means \pm standard errors. $z$-values and associated $p$-values were obtained from GLMM with a binomial negative distribution (zero-inflated models). Two values in the same row with a different letter are significantly different according to Tukey post hoc tests. ${ }^{* *}$ denotes statistical significance at $p=0.01$. When the $p$-values obtained from GLMM were not significant, the post hoc test results are not reported.

\begin{tabular}{|c|c|c|c|c|c|c|}
\hline & \multirow[b]{2}{*}{ z-Value } & \multirow[b]{2}{*}{$p$-Value } & \multicolumn{2}{|c|}{ Forest } & \multicolumn{2}{|c|}{ Meadow } \\
\hline & & & Control & Invaded & Control & Invaded \\
\hline \multicolumn{7}{|l|}{ Nematoda abundance } \\
\hline Knotweed & -1.43 & 0.15 & $351 \pm 98$ & $233 \pm 69$ & $941 \pm 490$ & $238 \pm 58$ \\
\hline Habitat & 0.89 & 0.37 & & & & \\
\hline Knotweed $\times$ Habitat & -0.94 & 0.35 & & & & \\
\hline \multicolumn{7}{|l|}{ bacterial feeder } \\
\hline Knotweed & -1.4 & 0.16 & $224 \pm 65$ & $149 \pm 52$ & $655 \pm 326$ & $180 \pm 55$ \\
\hline Habitat & 1.05 & 0.29 & & & & \\
\hline Knotweed $\times$ Habitat & -0.93 & 0.35 & & & & \\
\hline \multicolumn{7}{|l|}{ fungal feeder } \\
\hline Knotweed & -1.11 & 0.27 & $122 \pm 35$ & $81 \pm 29$ & $260 \pm 155$ & $52 \pm 6$ \\
\hline Habitat & 0.44 & 0.66 & & & & \\
\hline Knotweed $\times$ Habitat & -0.38 & 0.71 & & & & \\
\hline \multicolumn{7}{|l|}{ plant feeder } \\
\hline Knotweed & -2.86 & $0.004^{* *}$ & $14^{\mathrm{A}} \pm 5$ & $2^{B} \pm 0.8$ & $24^{\mathrm{A}} \pm 13$ & $4^{\mathrm{AB}} \pm 2$ \\
\hline Habitat & 0.28 & 0.78 & & & & \\
\hline Knotweed $\times$ Habitat & 1.04 & 0.3 & & & & \\
\hline \multicolumn{7}{|l|}{ omnivorous-predatory } \\
\hline Knotweed & -0.51 & 0.61 & $0.3 \pm 0.3$ & $0.2 \pm 0.2$ & $0.9 \pm 0.7$ & $0.3 \pm 0.2$ \\
\hline Habitat & 0.45 & 0.66 & & & & \\
\hline Knotweed $\times$ Habitat & -0.62 & 0.54 & & & & \\
\hline
\end{tabular}

\section{Discussion}

\subsection{Knotweed Effects on Native Plants and Soil Variables}

Knotweed invasion strongly reduced the heterogeneity of both forest and meadow habitats. Indeed, invasion by knotweeds led to a strongly significant decrease in native understory plant diversity in both meadows $(-62 \%)$ and forests $(-81 \%)$. Such negative effects of knotweed on plant diversity are well known and have been recently compiled in the review of Lavoie [12]: from 28 studies, 23 studies showed a negative effect of knotweed on plant diversity, and two studies found a null effect. Functional diversity was also reported to be lower in knotweed plots compared to control ones with a marked effect in meadows comparted to in forested areas [35]. In all these studies, this loss of diversity was coupled with a strong decrease in native plant cover and biomass [12]. In our study, native cover dropped by $80 \%$ on average, but this negative impact was higher in open habitat. Such Habitat $\times$ Knotweed interaction can be explained by the lowest ability of meadows species to compete for light compared to forest understory species. Indeed, the productivity, high stem density, and biomass (up to 13 times higher than the native one) of knotweeds contribute to the suppression of native understory species by competition for light and space [12]. In forest habitats, understory species are more adapted to low light availability, and have developed strategies to avoid light competition (e.g., liana: Hedera helix, Galium aparine), allowing them to climb over knotweeds. Thus, although invasion by knotweed did not lead to a change in the total plant cover (when including the contribution of knotweed), we can argue that knotweed invasion induced a strong 
alteration of habitat for soil fauna, with vegetation resource being less diverse and plant ground cover architecture being extremely reduced, and made only of knotweed stems. Indeed, knotweeds have shoots that can reach over $2 \mathrm{~m}$ in height, and these aerial parts (stems and leaves) die back to the ground in autumn, producing a threefold increase in litter amount compared to our control plots. This knotweed litter production (i.e., thickness) was similar between our two habitats. As hypothesized, this increase in litter following knotweed invasion was more significant in meadow habitats compared to forest habitats. The litter of knotweeds generally decomposes 3-4 times slower than litter of native species ([36], measurements in meadows) and is commonly of lower quality than the litter of the displaced plant species, thus potentially altering the nutrient cycling of the invaded ecosystems [37-39]. Most of the soil variables we measured responded to the knotweed invasion; for example, nitrate available for plants strongly increased in the invaded sites in meadow habitats and C:N ratio was highest in invaded forest habitats. Similarly to Stefanowicz et al. [40], our soils from forest-invaded plots had a much lower microbial biomass than soils from uninvaded plots. It is, therefore, possible that knotweed affects microbial biomass through competition for $\mathrm{N}$ due to the increase in soil $\mathrm{C}: \mathrm{N}$ ratio, and/or through allelopathy on microbial communities, which may ultimately cascade through Collembola and Nematoda groups feeding on these microorganisms. Knotweed invasion altered soil properties and simplified the habitat structure for soil fauna, but this effect is highly habitat dependent.

\subsection{Knotweed Effects on Collembola}

Overall, the presence of invasive knotweed led to reduce the total number of Collembola. Furthermore, as hypothesized, this negative effect was habitat dependent (significant interactive terms of Knotweed $\times$ Habitat) with an opposite response pattern of invasion in forests, where half of the Collembola disappeared compared to the invasion in meadows, with an increase in collembolan abundance of about $41.8 \%$. The importance of habitat characteristics or ecosystem type in invasion ecology was previously highlighted by other authors such as McCary et al. [7] and Liebhold et al. [41], suggesting that IAP rather indirectly influence soil fauna through modifications/alterations of environmental variables that may or not differ according to habitat type. Interestingly, this habitat-dependent differential response to the invasion of total Collembola was expressed by two of the three collembolan life-forms, the most and the less abundant, i.e., the hemiedaphic and the epedaphic, respectively. By contrast, the euedaphic species living deep in the soil were not significantly influenced by the presence of knotweed. This validates our hypothesis that collembolan species have contrasting responses to knotweed invasion according to their life-forms and that these responses were driven by contrasting ecological factors among different functional groups. Interestingly, euedaphic species not influenced by the presence of knotweed are assumed to be K-strategists and, therefore, more sensitive to changes in environmental conditions than r-strategists, such as epedaphic species [16] which can rapidly adapt to a fluctuating environment. Knotweed invasion strongly affects the vegetation community by changing the habitat for topsoil-living Collembola species, i.e., epedaphic and several hemiedaphic Collembola. Several studies previously highlighted the importance of vegetation community structure and composition as drivers of Collembola life-forms abundance [22,42]. Changes deeper in the soil, such as organic matter content or $\mathrm{pH}$, may be less important or may take more time to occur, and therefore be less important for euedaphic species that are used to coping with organic matter that is already processed. For example, euedaphic Collembola were shown to be much less reactive than epedaphic or hemiedaphic species to understory vegetation changes during forest clear-cutting [43]. From our results, it is clear that knotweed invasion in meadows led, first, to unfavorable habitat conditions or a trophic niche for epedaphic Collembola, and, second, to the promotion of hemiedaphic species. In contrast, in forests, the opposite pattern was found for the hemiedaphic species, and no response was found in the epedaphic Collembola. Although we do not have a clear explanation for the mechanisms behind these contrasting patterns, we can hypothesize that 
epedaphic species living in meadows, in contrast to species living in forests, are not used to dealing with a large amount of litter in autumn. Additionally, this monospecific litter also presents contrasted functional leaf attributes compared to monocotyledons leaves that are dominant in meadows. The presence of knotweed in meadows is radically changing the topsoil habitat with a high amount of litter. This may also have a strong effect on the available trophic resources for Collembola. The different collembolan life-forms are known to have distinct trophic regimes and this may also partly explain their differential responses to knotweed invasion in different habitat types [17]. Changes in abiotic variables, such as nitrate or soil humidity, are also more important in post-invasion meadows than in post-invasion forests, possibly affecting epedaphic and hemiedaphic species. Furthermore, we cannot exclude that secondary compounds released by knotweed roots or litter may differently interact with soil components in a forest or in a meadow soil, according to their chemical nature and/or physical matrices. Plant exudation is known to be controlled by soil abiotic variables such as $\mathrm{pH}$, temperature and humidity [44]. Regardless of the underlying mechanisms, however, changes in abundance of ep- and hemiedaphic species a few years after invasion may have considerable functional implications for soil processes. Surfacedwelling species have been shown, for example, to significantly enhance decomposition rates by facilitating the microbial use of organic matter [45-47].

\subsection{Knotweed Effects on Nematoda}

Overall, the total abundance of Nematodes we found in our study is comparable to abundances found in other studies reporting on riparian habitats in both forests or meadows [48-51]. The total abundance of Nematoda did not respond to the ingress of knotweed, regardless of the initial habitat structure. The abundance of total Nematodes seems to be positively correlated with plant species' richness and soil fungal biomass (i.e., ergosterol). We could not find any study in the literature reporting results on nematode abundances in the context of knotweed invasion. However, Abgrall et al. [13], in a microcosm experiment, found the total nematode abundance to significantly respond to knotweed rhizome extract; however, the direction of the effect (positive, neutral or negative) was dependent on the concentration of the rhizome extract, making a generalization difficult. Furthermore, Mc Cary et al. [7] and Abgrall et al. [8], in two meta-analyses, found the effect of invasive alien plant species on belowground fauna to depend on the feeding regime of the soil faunal group considered. Therefore, the lack of general effect on Nematodes in our case is not surprising, as Nematodes encompass a wide array of different trophic groups spanning from root herbivores to predators. Separating Nematodes into trophic groups helped us to reveal that plant feeders were the only trophic groups influenced by the invasion of knotweed, with their populations being strongly impoverished after knotweed invasion, either in forest or in meadow habitats. Plant feeders are primary consumers and have direct relationships with alien plant roots in the context of invasion. There is evidence for a high level of specificity aboveground, with over $90 \%$ of insect herbivores, for example, that feed only on plants belonging to a single genus or family [52]. Accordingly, McCary et al. [7] found that the abundance of aboveground herbivores declined in invaded areas dominated by one plant species, limiting the choice of resources for herbivores. Our results support this point of view. Furthermore, Asian knotweeds are known to deliver complex secondary metabolic compounds such as catechin or trans-resveratrol, which are known as being allelopathic [53-55]. Knotweed root systems consist of strong rhizomes with only a few fine roots. Both aspects (root architecture and release of allelopathic compounds) are likely to limit the accessibility of roots by plant feeders, explaining their strong decrease observed in our study. The decrease in microbial biomass observed in invaded plots compared to control plots did not lead to a significant decrease in microbivorous Nematodes, either bacterial or fungal feeders, even if a clear negative trend was observed, with a five-fold decrease and a three-fold decrease in bacterivores and fungivores in invaded plots compared to controls (forests and meadows merged together), respectively. Unfortunately, the statistical power was probably too weak to enable us to reveal statistical differences 
between treatments in this case. Finally, abundances of predators were relatively constant between all situations, supporting the idea that higher soil faunal trophic groups are less impacted than basal ones by the invasion of a plant species [8]. Brousseau et al. [35], at the same sites, also found that the lower species and functional diversity of plants in knotweed plots did not markedly cascade to the macrodetritivores and predators at either the taxonomic or the functional level. They also demonstrated that knotweed strongly reduced the trait matching (i.e., correlation between traits) between the functional diversity of detritivores and predators. Furthermore, a meta-analysis by Zhang et al. [56] showed that the effects of invasive plants can be separated into litter-based effects and rhizosphere effects, even though both compartments can facilitate plant invasion through positive feedback of nutrient cycling in soil systems. According to their research, invasive plant litter increases the abundance of aboveground decomposers, whereas the roots of invasive plants have a negative impact on belowground herbivores and predators. The latter also undergo changes in habitat structure due to the knotweed's rhizomes [57].

\section{Conclusions}

Further investigations are needed to clearly identify the abiotic or biotic factors responsible for changes in Collembola and Nematoda communities after knotweed invasion. However, our findings support the conclusions of previous studies by demonstrating that soil fauna abundance is impacted by plant invasions [58-60], with the initial habitat structure as a strong moderator of knotweed presence outcome [8]. Responses within the soil fauna also differ between trophic levels and life-forms, potentially leading to different food-web structures and performances. Our results reveal the need to further investigate belowground response to IAP because, in the context of biological invasions, the importance of plant species' identity and composition as drivers of soil biodiversity is predominant $[6,61]$. This is most likely explained by trait differences between plant species, which can determine litter quality and physical structure, with subsequent consequences for trophic resources and microhabitat conditions [6,62].

Supplementary Materials: The following are available online at https:/ / www.mdpi.com/article / $10.3390 /$ d14020061/s1, Table S1: Study sites description with the dominant plant species found in control sites, Table S2: Full dataset of soil variables (abiotic and biotic) and vegetation in 6 studied sites invaded or not by Asian knotweed.

Author Contributions: Conceptualization, T.D.A., M.C. and E.F.; methodology, T.D.A., M.C. and E.F.; validation, T.D.A., M.C. and E.F.; formal analysis, T.D.A., M.C. and E.F.; investigation, T.D.A., M.C. and E.F.; resources, T.D.A., M.C. and E.F.; data curation, T.D.A.; writing-original draft preparation, T.D.A., M.C. and E.F.; writing-review and editing, T.D.A., M.C. and E.F.; funding acquisition, E.F. and M.C. All authors have read and agreed to the published version of the manuscript.

Funding: This research was partly funded by "the Agence de l'Eau Seine-Normandie-AESN".

Institutional Review Board Statement: Not applicable.

Informed Consent Statement: Not applicable.

Data Availability Statement: Data are available as part of the Supplementary Material.

Acknowledgments: We thank the Ecodiv lab members for field and laboratory assistance as well as the AESN for site accessibility.

Conflicts of Interest: The authors declare no conflict of interest. The funders had no role in the design of the study; in the collection, analyses, or interpretation of data; in the writing of the manuscript, or in the decision to publish the results. 


\section{References}

1. Vilà, M.; Espinar, J.L.; Hejda, M.; Hulme, P.E.; Jarošík, V.; Maron, J.L.; Pergl, J.; Schaffner, U.; Sun, Y.; Pyšek, P. Ecological impacts of invasive alien plants: A meta-analysis of their effects on species, communities and ecosystems. Ecol. Lett. 2011, 14, 702-708. [CrossRef]

2. Pyšek, P.; Jarošík, V.; Hulme, P.E.; Pergl, J.; Hejda, M.; Schaffner, U.; Vilà, M. A global assessment of invasive plant impacts on resident species, communities and ecosystems: The interaction of impact measures, invading species' traits and environment. Glob. Change Biol. 2012, 18, 1725-1737. [CrossRef]

3. Diagne, C.; Leroy, B.; Vaissière, A.-C.; Gozlan, R.E.; Roiz, D.; Jarić, I.; Salles, J.-M.; Bradshaw, C.J.A.; Courchamp, F. High and rising economic costs of biological invasions worldwide. Nature 2021, 592, 571-576. [CrossRef]

4. Schirmel, J.; Bundschuh, M.; Entling, M.H.; Kowarik, I.; Buchholz, S. Impacts of invasive plants on resident animals across ecosystems, taxa, and feeding types: A global assessment. Glob. Change Biol. 2016, 22, 594-603. [CrossRef]

5. Callaway, R.M.; Ridenour, W.M. Novel weapons: Invasive success and the evolution of increased competitive ability. Front. Ecol. Environ. 2004, 2, 436-443. [CrossRef]

6. Forey, E.; Lodhar, S.; Gopaul, S.; Boehmer, H.J.; Chauvat, M. A functional trait-based approach to assess the impact of an alien palm invasion on plant and soil communities on a South Pacific island. Austral Ecol. 2021, 46, 398-410. [CrossRef]

7. McCary, M.A.; Mores, R.; Farfan, M.A.; Wise, D.H. Invasive plants have different effects on trophic structure of green and brown food webs in terrestrial ecosystems: A meta-analysis. Ecol. Lett. 2016, 19, 328-335. [CrossRef] [PubMed]

8. Abgrall, C.; Forey, E.; Chauvat, M. Soil fauna responses to invasive alien plants are determined by trophic groups and habitat structure: A global meta-analysis. Oikos 2019, 128, 1390-1401. [CrossRef]

9. Wardle, D.A.; Peltzer, D.A. Impacts of invasive biota in forest ecosystems in an aboveground-belowground context. Biol. Invasions 2017, 19, 3301-3316. [CrossRef]

10. Aldorfová, A.; Knobová, P.; Münzbergová, Z. Plant-soil feedback contributes to predicting plant invasiveness of 68 alien plant species differing in invasive status. Oikos 2020, 129, 1257-1270. [CrossRef]

11. Martin, F.-M. The Study of the Spatial Dynamics of Asian Knotweeds (Reynoutria spp.) across Scales and its Contribution for Management Improvement. Ph.D. Thesis, Université Grenoble Alpes, Grenoble, France, 2019.

12. Lavoie, C. The impact of invasive knotweed species (Reynoutria spp.) on the environment: Review and research perspectives. Biol. Invasions 2017, 19, 2319-2337. [CrossRef]

13. Abgrall, C.; Forey, E.; Mignot, L.; Chauvat, M. Invasion by Fallopia japonica alters soil food webs through secondary metabolites. Soil Biol. Biochem. 2018, 127, 100-109. [CrossRef]

14. Skubala, P.; Mierny, A. Invasive Reynoutria taxa as a contaminant of soil. Does it reduce abundance and diversity of microarthropods and damage soil habitat? Pestycydy 2009, 1-4, 57-62.

15. Chauvat, M.; Perez, G.; Ponge, J.-F. Foraging patterns of soil springtails are impacted by food resources. Appl. Soil Ecol. 2014, 82, 72-77. [CrossRef]

16. Petersen, H. General aspects of collembolan ecology at the turn of the millennium: Proceedings of the Xth international colloquium on Apterygota, České Budějovice 2000: Apterygota at the beginning of the third millennium. Pedobiologia 2002, 46, 246-260. [CrossRef]

17. Potapov, A.A.; Semenina, E.E.; Korotkevich, A.Y.; Kuznetsova, N.A.; Tiunov, A. V Connecting taxonomy and ecology: Trophic niches of collembolans as related to taxonomic identity and life forms. Soil Biol. Biochem. 2016, 101, 20-31. [CrossRef]

18. Potapov, A.M.; Pollierer, M.M.; Salmon, S.; Šustr, V.; Chen, T. Multidimensional trophic niche revealed by complementary approaches: Gut content, digestive enzymes, fatty acids and stable isotopes in Collembola. J. Anim. Ecol. 2021, 92, 161-188. [CrossRef]

19. Rusek, J. Biodiversity of Collembola and their functional role in the ecosystem. Biodivers. Conserv. 1998, 7, 1207-1219. [CrossRef]

20. Chauvat, M.; Wolters, V.; Dauber, J. Response of collembolan communities to land-use change and grassland succession. Ecography 2007, 30, 183-192. [CrossRef]

21. da Silva, P.M.; Carvalho, F.; Dirilgen, T.; Stone, D.; Creamer, R.; Bolger, T.; Sousa, J.P. Traits of collembolan life-form indicate land use types and soil properties across an European transect. Appl. Soil Ecol. 2016, 97, 69-77. [CrossRef]

22. Henneron, L.; Aubert, M.; Archaux, F.; Bureau, F.; Dumas, Y.; Ningre, F.; Richter, C.; Balandier, P.; Chauvat, M. Forest plant community as a driver of soil biodiversity: Experimental evidence from collembolan assemblages through large-scale and long-term removal of oak canopy trees Quercus petraea. Oikos 2017, 126, 420-434. [CrossRef]

23. Yin, R.; Gruss, I.; Eisenhauer, N.; Kardol, P.; Thakur, M.P.; Schmidt, A.; Xu, Z.; Siebert, J.; Zhang, C.; Wu, G.-L. Land use modulates the effects of climate change on density but not community composition of Collembola. Soil Biol. Biochem. 2019, 138, 107598. [CrossRef]

24. Jenkinson, D.S.; Powlson, D.S. The effects of biocidal treatments on metabolism in soil-I. Fumigation with chloroform ... V. A method for measuring soil biomass. Soil Biol. Biochem. 1976, 8, 179. [CrossRef]

25. Gong, P.; Guan, X.; Witter, E. A rapid method to extract ergosterol from soil by physical disruption. Appl. Soil Ecol. 2001, 17, 285-289. [CrossRef]

26. Braun-Blanquet, J.; Roussine, N.; Nègre, R.; Emberger, L. Les Groupements Végétaux de la France Méditerranéenne; CNRS Edition: Paris, France, 1952.

27. Macfadyen, A. Improved funnel-type extractors for soil arthropods. J. Anim. Ecol. 1961, 30, 171-184. [CrossRef] 
28. Gisin, H. Ökologie und Lebensgemeinschaften der Collembolen im Schweizerischen Exkursionsgebiet Basel, Inauguraldissertation; Universität Basel: Basel, Switzerland, 1943.

29. Barker, K.R. Nematode Extraction and Bioassays; Barker, K., Barker, K.R., Carter, C.C., Sasser, J.N., Eds.; North Carolina State University Graphics: Raleigh, NC, USA, 1985.

30. Yeates, G.W.; Bongers, T.; De Goede, R.G.M.; Freckman, D.W.; Georgieva, S.S. Feeding habits in soil nematode families and genera-an outline for soil ecologists. J. Nematol. 1993, 25, 315-331.

31. Magnusson, A.; Skaug, H.; Nielsen, A.; Berg, C.; Kristensen, K.; Maechler, M.; van Bentham, K.; Bolker, B.; Brooks, M.; Brooks, M.M. Package 'glmmTMB.' R Packag. Version 0.2. 0. 2017. Available online: http://cran.uni-muenster.de/web/packages/ glmmTMB/glmmTMB.pdf (accessed on 15 January 2021).

32. Brooks, M.E.; Kristensen, K.; van Benthem, K.J.; Magnusson, A.; Berg, C.W.; Nielsen, A.; Skaug, H.J.; Mächler, M.; Bolker, B.M. glmmTMB balances speed and flexibility among packages for zero-inflated generalized linear mixed modeling. $R J$. 2017, 9, 378-400. [CrossRef]

33. Oksanen, J.; Blanchet, F.; Kindt, R.; Legendre, P.; O’Hara, R. Vegan: Community ecology package. R Packag. 2016,2 , 2-3.

34. Lê, S.; Josse, J.; Husson, F. FactoMineR: An R package for multivariate analysis. J. Stat. Softw. 2008, 25, 1-18. [CrossRef]

35. Brousseau, P.-M.; Chauvat, M.; De Almeida, T.; Forey, E. Invasive knotweed modifies predator-prey interactions in the soil food web. Biol. Invasions 2021, 23, 1987-2002. [CrossRef]

36. Mincheva, T.; Barni, E.; Varese, G.C.; Brusa, G.; Cerabolini, B.; Siniscalco, C. Litter quality, decomposition rates and saprotrophic mycoflora in Fallopia japonica (Houtt.) Ronse Decraene and in adjacent native grassland vegetation. Acta Oecol. 2014, 54, 29-35. [CrossRef]

37. Urgenson, L.S.; Reichard, S.H.; Halpern, C.B. Community and ecosystem consequences of giant knotweed (Polygonum sachalinense) invasion into riparian forests of western Washington, USA. Biol. Conserv. 2009, 142, 1536-1541. [CrossRef]

38. Mincheva, T.; Barni, E.; Siniscalco, C. From plant traits to invasion success: Impacts of the alien Fallopia japonica (Houtt.) Ronse Decraene on two native grassland species. Plant Biosyst. Int. J. Deal. Asp. Plant Biol. 2016, 150, 1348-1357. [CrossRef]

39. Bardon, C.; Poly, F.; el Zahar Haichar, F.; Le Roux, X.; Simon, L.; Meiffren, G.; Comte, G.; Rouifed, S.; Piola, F. Biological denitrification inhibition (BDI) with procyanidins induces modification of root traits, growth and N status in Fallopia $x$ bohemica. Soil Biol. Biochem. 2017, 107, 41-49. [CrossRef]

40. Stefanowicz, A.M.; Kapusta, P.; Stanek, M.; Frąc, M.; Oszust, K.; Woch, M.W.; Zubek, S. Invasive plant Reynoutria japonica produces large amounts of phenolic compounds and reduces the biomass but not activity of soil microbial communities. Sci. Total Environ. 2021, 767, 145439. [CrossRef]

41. Liebhold, A.M.; Brockerhoff, E.G.; Kalisz, S.; Nuñez, M.A.; Wardle, D.A.; Wingfield, M.J. Biological invasions in forest ecosystems. Biol. Invasions 2017, 19, 3437-3458. [CrossRef]

42. Perez, G.; Decaëns, T.; Dujardin, G.; Akpa-Vinceslas, M.; Langlois, E.; Chauvat, M. Response of collembolan assemblages to plant species successional gradient. Pedobiologia 2013, 56, 169-177. [CrossRef]

43. Chauvat, M.; Zaitsev, A.S.; Wolters, V. Successional changes of Collembola and soil microbiota during forest rotation. Oecologia 2003, 137, 269-276. [CrossRef]

44. Badri, D.V.; Vivanco, J.M. Regulation and function of root exudates. Plant. Cell Environ. 2009, 32, 666-681. [CrossRef]

45. Takeda, H. A 5 year study of pine needle litter decomposition in relation to mass loss and faunal abundances. Pedobiologia 1988, 32, 221-226.

46. Faber, J.H.; Teuben, A.; Berg, M.P.; Doelman, P. Microbial biomass and activity in pine litter in the presence of Tomocerus minor (Insecta, Collembola). Biol. Fertil. Soils 1992, 12, 233-240. [CrossRef]

47. Hasegawa, M.; Takeda, H. Changes in feeding attributes of four collembolan populations during the decomposition process of pine needles. Pedobiologia 1995, 39, 155-169.

48. Young-Mathews, A.; Culman, S.W.; Sánchez-Moreno, S.; O'Geen, A.T.; Ferris, H.; Hollander, A.D.; Jackson, L.E. Plant-soil biodiversity relationships and nutrient retention in agricultural riparian zones of the Sacramento Valley, California. Agrofor. Syst. 2010, 80, 41-60. [CrossRef]

49. Briar, S.S.; Culman, S.W.; Young-Mathews, A.; Jackson, L.E.; Ferris, H. Nematode community responses to a moisture gradient and grazing along a restored riparian corridor. Eur. J. Soil Biol. 2012, 50, 32-38. [CrossRef]

50. Čerevková, A.; Bobul'ská, L.; Miklisová, D.; Renčo, M. A case study of soil food web components affected by Fallopia japonica (Polygonaceae) in three natural habitats in Central Europe. J. Nematol. 2019, 51, e2019-42. [CrossRef]

51. Renčo, M.; Čerevková, A.; Homolová, Z. Nematode communities indicate the negative impact of Reynoutria japonica invasion on soil fauna in ruderal habitats of tatra national park in Slovakia. Glob. Ecol. Conserv. 2021, 26, e01470. [CrossRef]

52. Ali, J.G.; Agrawal, A.A. Specialist versus generalist insect herbivores and plant defense. Trends Plant Sci. 2012, 17, 293-302. [CrossRef]

53. Vrchotová, N.; Šerá, B. Allelopathic properties of knotweed rhizome extracts. Plant Soil Environ. 2008, 54, 301-303. [CrossRef]

54. Vrchotová, N.; Sera, B.; Triska, J. The stilbene and catechin content of the spring sprouts of Reynoutria species. Acta Chromatogr. 2007, 19, 21-28.

55. Vastano, B.C.; Chen, Y.; Zhu, N.; Ho, C.-T.; Zhou, Z.; Rosen, R.T. Isolation and identification of stilbenes in two varieties of polygonum c uspidatum. J. Agric. Food Chem. 2000, 48, 253-256. [CrossRef] 
56. Zhang, P.; Li, B.; Wu, J.; Hu, S. Invasive plants differentially affect soil biota through litter and rhizosphere pathways: A meta-analysis. Ecol. Lett. 2019, 22, 200-210. [CrossRef] [PubMed]

57. Bailey, J.P.; Bímová, K.; Mandák, B. Asexual spread versus sexual reproduction and evolution in Japanese Knotweed s.l. sets the stage for the "battle of the Clones". Biol. Invasions 2009, 11, 1189-1203. [CrossRef]

58. Morriën, E.; Duyts, H.; Van der Putten, W.H. Effects of native and exotic range-expanding plant species on taxonomic and functional composition of Nematodes in the soil food web. Oikos 2012, 121, 181-190. [CrossRef]

59. Tanner, R.A.; Varia, S.; Eschen, R.; Wood, S.; Murphy, S.T.; Gange, A.C. Impacts of an invasive non-native annual weed, Impatiens glandulifera, on above-and below-ground invertebrate communities in the United Kingdom. PLoS ONE 2013, 8, e67271. [CrossRef]

60. Maceda-Veiga, A.; Basas, H.; Lanzaco, G.; Sala, M.; De Sostoa, A.; Serra, A. Impacts of the invader giant reed (Arundo donax) on riparian habitats and ground arthropod communities. Biol. Invasions 2016, 18, 731-749. [CrossRef]

61. Wardle, D.A. How plant communities influence decomposer communities. Biol. Divers. Funct. Soils 2005, 119-138. [CrossRef]

62. Wardle, D.A. The influence of biotic interactions on soil biodiversity. Ecol. Lett. 2006, 9, 870-886. [CrossRef] 